\title{
Beyond shelter: the urban house as an entrepreneurial resource
}

\author{
Shantanu Bindumadhav Khandkar MArch \\ Visiting Professor, University of Mumbai, Mumbai, Maharashtra, India \\ (corresponding author: shantanu.khandkar@gmail.com)
}

Janhavi Shantanu Khandkar MArch

Assistant Professor, University of Mumbai, Mumbai, Maharashtra, India

For the urban poor, a house represents more than shelter. It is also a resource which can be used for generating income and thus plays an important role in the economy. Since independence, policies adopted by successive governments in India to address the problem of housing for the urban poor have undergone considerable changes. The government's role has shifted from being a direct provider to an enabler. The design processes and delivery mechanisms for housing are concerned with addressing only the need or demand for shelter. On the contrary, in scenarios where the people have had a more active role in the production of housing, it has been observed that the house is not just seen as shelter but also as a place adaptable for income generation, thereby enabling it to play an important role in the informal well as, in some cases, formal economy. By studying various housing typologies found in the city of Mumbai and the legislative, financial and operative models that produced them, the paper argues that the lack of these characteristics in the final product is one of the reasons for the government housing schemes finding limited success.

\section{Introduction}

This paper is an investigation into the role played by housing in the livelihood strategies of the urban poor. It makes two main arguments, namely that the urban house is an entrepreneurial resource which the urban poor use as a mode of income generation and that such housing has specific attributes, which are brought about by the action of certain mechanisms that need to be investigated.

Shetty's (2005) research paper 'Stories of Entrepreneurship' speaks of a new structure for the city of Mumbai based on new patterns of development observed in the post-liberalisation era of the 1990s. The regional plan drafted by the Mumbai Metropolitan Region Development Authority (MMRDA) shows that the manufacturing sector, which was the dominant employer in the 1960s and the 1970s has given way to the service sector. In light of the changing production and consumption patterns, the paper speaks of the emergence of a new structure of the city as a city of entrepreneur agents. The means of production are no longer centralised under a single ownership but have shifted to various production units scattered around the globe.

In light of this new decentralised structure of the urban economy, it becomes necessary to look at the ways in which the urban landscape is being shaped.

\section{Structure and methodology}

This paper is structured into four parts.

Part I gives a brief historical overview of the various attempts made by Indian governments since independence to provide affordable housing to the urban poor with some remarks on their successes and failures.

Part II frames the issue that the paper is dealing with. It attempts to show that a major reason for the less than satisfactory rate of success of the attempts towards housing provision is the dissatisfaction of the beneficiaries with the housing provided through formal mechanisms, vis-à-vis user-generated informal housing solutions.

Part III investigates the multifaceted meaning of housing for the urban poor. Morphological studies of certain housing types around Mumbai are undertaken, establishing the built form aspects such as spatial configurations, materials, location and so on Finally, the legislative, financial and operative mechanisms that led to their evolution are investigated.

Part IV looks at the urban house as part of a network and the aspects which affect the role of the house as an entrepreneurial resource and summarise the built form attributes and underlying mechanisms that are essential for housing to play this role.

\section{Part I affordable housing in India: a brief overview}

In the years immediately following independence, the state was the dominant player in housing provision, with the private sector playing only a limited role. Housing was seen as a welfare and hence the emphasis was on reducing the cost of housing through innovations in building technology and materials. Further, housing was provided at heavily subsidised prices to target demographics. However, this often led to the housing thus provided being sold off to higher 
income groups to gain the profit. The housing provided was often unaffordable or at unsuitable locations for the target demographic. The pure subsidy approach was also a drain on the exchequer and thus the supply for housing could not keep up with the demand. Where slum clearance schemes failed to rehabilitate all those who had been evicted, it led to a net destruction of housing stock (Hingorani, 2011a).

By the 1970s, the limits of the subsidy-driven approach had become apparent, and hence the focus shifted to upgradation of existing slums and site and services schemes (Hingorani, 2011a). These were also deemed as failures. The site and services projects had to be sited at peripheral locations in order to make them affordable. The added transportation and development costs placed a greater financial burden on to the beneficiaries. At the same time, the sites were attractive to the middle and higher income groups and were soon grabbed by them (Wadhwa, 1988).

A major change came in 1987 when the first National Housing Policy envisioned a more facilitative rather than direct role for the government (Hingorani, 2011a, 2011b). This gave a greater role to the private sector. While the private sector does provide some housing for all groups, the provision is far from adequate, especially for the poor. High land prices, cost of construction, transaction costs, legal charges and taxes, and the profit margin of private developers have made the housing costs unaffordable. There is a surplus in some segments and shortage in others, as evidenced by the high vacancy rate in urban housing (Wadhwa, 2009).

On one hand, formal attempts at housing provision for the urban poor have had a less than satisfactory rate of success. On the other, the urban poor and, in some cases, even higher income groups have been forced to provide housing for themselves through informal means due to lack of choice, leading to an increase in the slum-dwelling population. While slums tend to provide substandard quality of housing, a lack of secure tenure and limited access to infrastructure, they also provide certain benefits, such as affordability, adaptability and locational suitability (Gulyani and Bassett, 2010).

\section{Part II framing the issue}

On June 18, 2007, the residents of Dharavi, a large informal settlement located at the heart of Mumbai carried out a Black Flag protest rally. The agenda of the protest rally was to convey to the authorities the residents' opposition to the Dharavi Redevelopment Plan (SPARC and KRVIA, 2010).

Dharavi, home to about 600000 residents, has often been called 'Asia's largest slum'. It is located on the prime real estate near the commercial centre of Bandra-Kurla complex. Dharavi began as a small fishing settlement located at the northern tip of Parel Island, one of the seven islands of the archipelago that became the city of Mumbai. The city started developing around the Port of Bombay in the southern part of the archipelago after the English built the fort and town of Bombay in the seventeenth century. Bombay soon developed into a major trading centre, attracting a large number of migrants from the rest of India. The 'white and blue collared' workers (so designated here as they were formally employed with some rights and security) soon found accommodation in the burgeoning native town around the English fort. The poorer labourers who couldn't afford to live near the town centre were left to reclaim the marshes around Dharavi to provide housing for themselves. Over the next centuries, as more and more migrants poured into the city, this informal settlement at the northern fringes also grew into a large slum, ultimately being engulfed by the ever northwards growing city.

Several policies were implemented over the years to ameliorate what were seen as the poor living conditions in Dharavi and other such settlements spread around the city. In 1985, the erstwhile prime minister of India, Mr. Rajiv Gandhi allocated Rs. 100 crores (about US $\$ 80.7$ million) for the improvement of infrastructures in Bombay. About a third of that amount was reserved for Dharavi.

In 1995, the Government of Maharashtra launched the slum rehabilitation scheme. Under this scheme, private developers build free housing of a minimum specified size for eligible slum dwellers in return for additional development rights to be used for building market rate housing on slum lands. The slum rehabilitation authority was constituted and empowered as an autonomous body in 1997 for the specific purpose of running this scheme. In 2004, the Government of Maharashtra accepted the Dharavi Redevelopment Plan. The plan called for dividing Dharavi into five sectors and calling in bids from around the world for providing housing and infrastructure for the residents in return for extra development rights to earn profit through the exploitation of land values.

The slum dwellers, who were supposed to be the primary beneficiaries of the plan raised objections against it from the onset. According to Sunder Burra, advisor to the Society for Promotion of Area Resource Centres (SPARC), a Mumbaibased NGO, the main issue was that the entire plan was conceived without any community participation (SPARC \& KRVIA, 2010).

In February 2009, a Committee of Experts (CoE) was constituted to advise the government on the redevelopment process. In a letter to Mr. Sitaram Kunte, secretary, Housing Department, dated 3 June 2009, the CoE observes that for a project of this magnitude, there should have been '... a detailed socio-economic survey of Dharavi, besides a plane-table and 
topographical survey, transportation studies, infrastructure and environmental assessment studies etc.'. The letter goes on to say that the CoE was '... appalled to find that no such surveys and studies had been done and the bids were invited probably on the false assurance of the consultants that these studies were either already conducted or were not necessary' (SPARC \& KRVIA, 2010).

The opposition of the residents of Dharavi to the plan foregrounds two important issues. The first is the necessity of community participation in the process of housing provision for the urban poor. Without this, the idea of development itself gets negated as the aspirations of the beneficiaries are not reflected in the process. The second issue is closely intertwined with the first. The situation in Dharavi is representative of a common characteristic of most housing policies developed by successive governments in India. When it comes to housing, these policies are focused primarily on provision of legal tenure and sufficient living space. In addition, for the urban poor, a house is expected to perform duties that go beyond this. The residents of Dharavi were up in arms against redevelopment because the urban form and built spaces as envisaged by the Dharavi Redevelopment Plan would have destroyed their livelihoods. This would have made it impossible for them to continue living in Dharavi and they would have been forced to relocate to places better suited to their livelihood strategies. This has been the case with this public-private partnership model being implemented in other cases in Mumbai as well. According to the National Alliance of People's Movements (NAPM), up to $35 \%$ of the beneficiaries have already sold or rented out their new houses and moved back into slums (Hingorani, 2011a).

Any housing scheme which does not involve community participation and does not recognise the economic role of housing is bound to face the same issue. Even before the public-private partnership approach was envisaged, dissatisfaction with state provided housing was evident. The housing provided, being ill suited to the specific needs of the beneficiaries, were deemed 'unaffordable and unacceptable' and disposed of. As there was a high amount of subsidy involved to make the housing affordable, it became an attractive option for the beneficiaries to sell the units to higher income groups and capture the profits (Wadhwa, 1988). While this is often attributed to the greed of the beneficiaries, the primary reason for dissatisfaction was the disruption in the socio-cultural and economic patterns, which had been formulated as part of the livelihood strategies.

\section{Housing and what it means to the urban poor}

As Smets (2004) points out, owning a house in a city means many things beyond shelter for the urban poor. First, ownership of a house affords the kind of status in society that the possession of things such as cattle, tools, ancestry symbols and so on would provide. In general, a person who owns a house and is able to invest in its upkeep and improvement is seen as more credit worthy and thus eligible to participate in community enterprises. Second, a house serves a specific socio-cultural function. For example, newly married couples acquiring a dwelling of their own assert their position as a separate household or nuclear family unit. Third, by renting out a part of the house for residential or commercial purposes, the house can help in generating income. Fourth, part of the house can be used as a workspace, retail space or storage space. Fifth, the owned house can be used as collateral in order to raise finance for an entrepreneurial enterprise through financial self-help groups, to raise a loan from banks, family, friends or neighbours.

Therefore, the design of the housing unit must be equipped with the flexibility to accommodate such varied functions. The ability to change and expand over time is a pertinent aspect of designing affordable housing. Also, the house must be seen as an asset, perhaps the most valuable asset that the family may possess. It is not unreasonable to expect the value of the asset to enhance over time. For this to happen, situations which favour investments on the house must be brought about.

The poor tend to build and improve their dwellings incrementally (Smets, 2004). Such incremental improvements depend on several factors such as family size, stages in family cycle, household priorities and the means available. Thus, it becomes clear that building a house is a process. Standard products provided by large enterprises cannot address the constantly changing and varied needs of the households. Furthermore, developing housing incrementally as opposed to building it in one go also calls for the availability of sources of housing finance as and when the need arises. This finance can be raised through various means. Self-help organisations, loans from banks or from friends, family, neighbours, money lenders and so on are some of the sources of finance. The amount of loan required depends on the construction costs minus any subsidies provided by government bodies and the owner's resources such as down payment, building materials and labour (Smets, 2004).

\section{Housing and affordability}

Affordability is a subjective term, taking into consideration many criteria. These include the loan repayment capacity, the rent-paying capacity and the investment capacity as a proportion of the monthly or yearly income of the household. It is thought that investment in shelter requires long-term planning. A large loan must be paid off over a long period of time. Thus, it is necessary to also take into consideration the anticipated income of the household. Since part of the shelter can be used to generate income, this can be incorporated into the calculation of its affordability (Smets, 2004). 
Subsequently, one must also look at the term 'affordability' in the context of other terms that make for a viable housing solution. One such term is 'adequacy'. Adequate housing depends on factors such as family size, composition, age structure, profession and so on. Making a house 'affordable' is seen as a reduction in the price of the product by reducing the standards or through direct subsidy. Reducing the standards and size of the housing unit affects adequacy and quality of the product. An affordable house of adequate size and quality means a compromise on the location. Feasibility demands that such housing schemes be located in far-flung areas where land costs are lower. This, however, means a greater burden in terms of travelling cost and time for the beneficiary. As most of the urban poor are employed in the informal sector, an increase in travelling time means a reduction in working time and thus a reduction in income (Wadhwa, 2009).

\section{Part III case studies}

The following case studies have been identified to illustrate the various points discussed above. They represent different situations in terms of the type tenure, user profile, the mechanisms for housing provision, formality/informality, level of end-user intervention and the uses to which the house is employed.

The first case is a settlement of potters which is now a part of Dharavi. The case demonstrates a situation where people belonging to a common profession built their own settlement with little to no formal intervention.

The second case is a site-and-services scheme, which shows the incremental changes made to the core houses provided to the beneficiaries with access to secure tenure and infrastructure. The case will show how the houses slowly evolved from providing only shelter to be the third case is a community-driven resettlement scheme which is significant due to the mechanism which involved the beneficiaries in the decision-making process and also for the strategies evolved by the beneficiaries themselves in making housing finance available. The fourth case shows the result of housing provided by formal state mechanism without any end-user participation and with focus purely on tenure (Figure 1).

\section{Case 1: Kumbharwada}

Kumbharwada ('Potters' colony'), as the name suggests, is a settlement of potters located at the southern end of Dharavi. It occupies about 5 hectares of land and is home to about 9500 people. Kumbharwada came into existence around the beginning of the twentieth century when potters from Gujarat migrated to Mumbai and made their homes along with other communities in the marshes surrounding Dharavi. In the 1930s, the Municipal Corporation of Greater Mumbai (MCGM) (then known as Bombay Municipal Corporation
(BMC)) gave a vacant land tenancy (VLT) to the Prajapati Sahakari Utpadak Mandal, a co-operative society of potters, to carry out pottery-related activities. VLTs were created by BMC to protect vacant land under its ownership from encroachments. As per the MCGM Estates Department, rents from these lands amount to the extent of INR 52.95 lakhs ( $\sim$ US\$73 000) per annum. VLTs are being reduced by means of creating long-term leases on lands not reserved for any other purpose and by redevelopment of other properties.

Out of the approximately 350 original tenants, about 120 currently have small kilns and are still engaged in pottery. Most of the vacant land is now constructed on with slum-like structures and are being used for residential or commercial activities. The VLTs have rented out some buildings to sub-tenants and are earning rental income or have sold the buildings to new owners. Due to this, the MCGM cancelled the VLT in 2010 (JJCOA and CRIT, 2010).

Considering the nature of the work which requires day-long involvement and with a meagre income, the houses are built to double as workplaces (Figure 2). This minimises travelling time and cost. The houses in Kumbharwada are long and narrow structures. These structures are set in long rows. The areas between two such rows form the streets and open spaces which house the kilns, workspaces and storage spaces for the pottery business (Figure 3). Houses which have frontage on the main roads have shops for selling the products (Figure 4). Most of the houses are single or double storeyed. The ground storeys are built in brick or sometimes with timber framing clad with tin sheets. Upper storeys are built with timber or steel framing and tin sheet cladding. Part of the house is used as a storage space for raw materials and finished products (Figure 2).

\section{Case 2: Charkop site and services scheme}

The World Bank funded Bombay urban development project (BUDP) was launched in 1985 with two programmes, namely the slum upgradation programme (SUP) and the land infrastructure servicing programme (LISP). Under LISP, the Maharashtra Housing and Area Development Authority (MHADA) was made the implementing authority with a mandate to generate 40000 serviced sites in Greater Mumbai for providing affordable housing. Out of the INR 282.33 crore ( $\sim$ US $\$ 228$ million) the project cost for BUDP, 196.25 crores were allocated for LISP. A total of $58 \%$ of the finance was loaned by the International Development Association (IDA), $26 \%$ from beneficiary contribution and the rest as a government loan to the implementing authority (MHADA, 1987). MMRDA would be the project coordinator and off-site infrastructure provided by MCGM. One of the sites chosen was near the village of Charkop in the suburb of Kandivali. The plot was land affected by tidal variations which had to be reclaimed. 


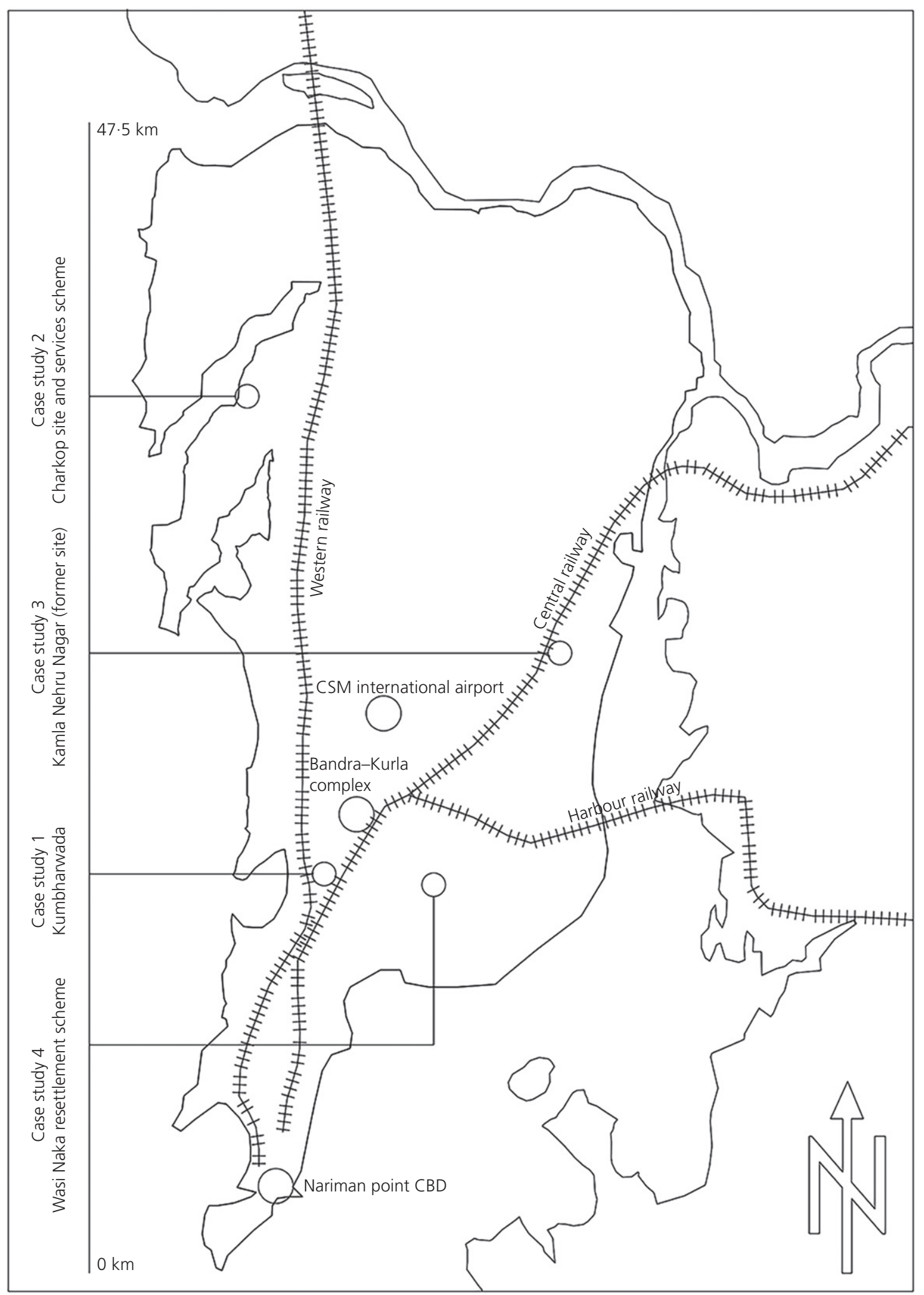

Figure 1. Locations of case study areas within the urban context of Mumbai (source: author) 
Urban Design and Planning

Volume 172 Issue DP2
Beyond shelter: the urban house as an

entrepreneurial resource

Khandkar and Khandkar

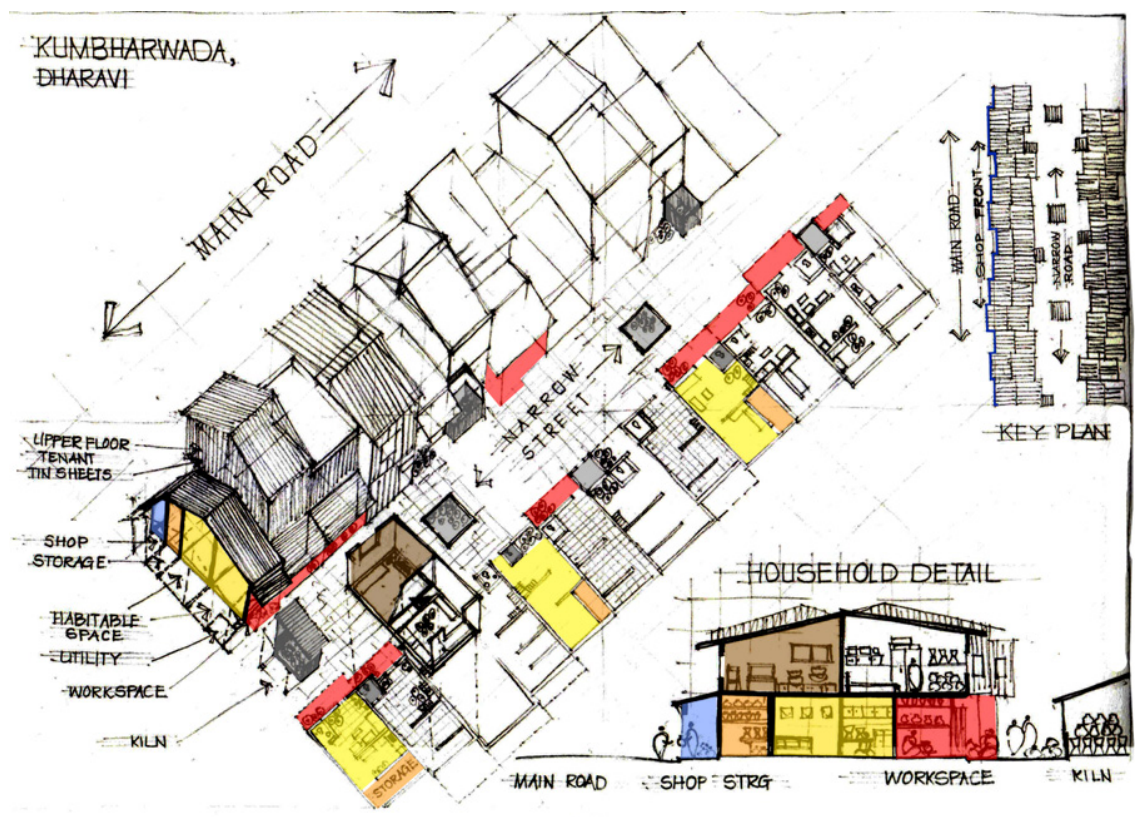

Figure 2. Built form studies, Kumbharwada (source: author)

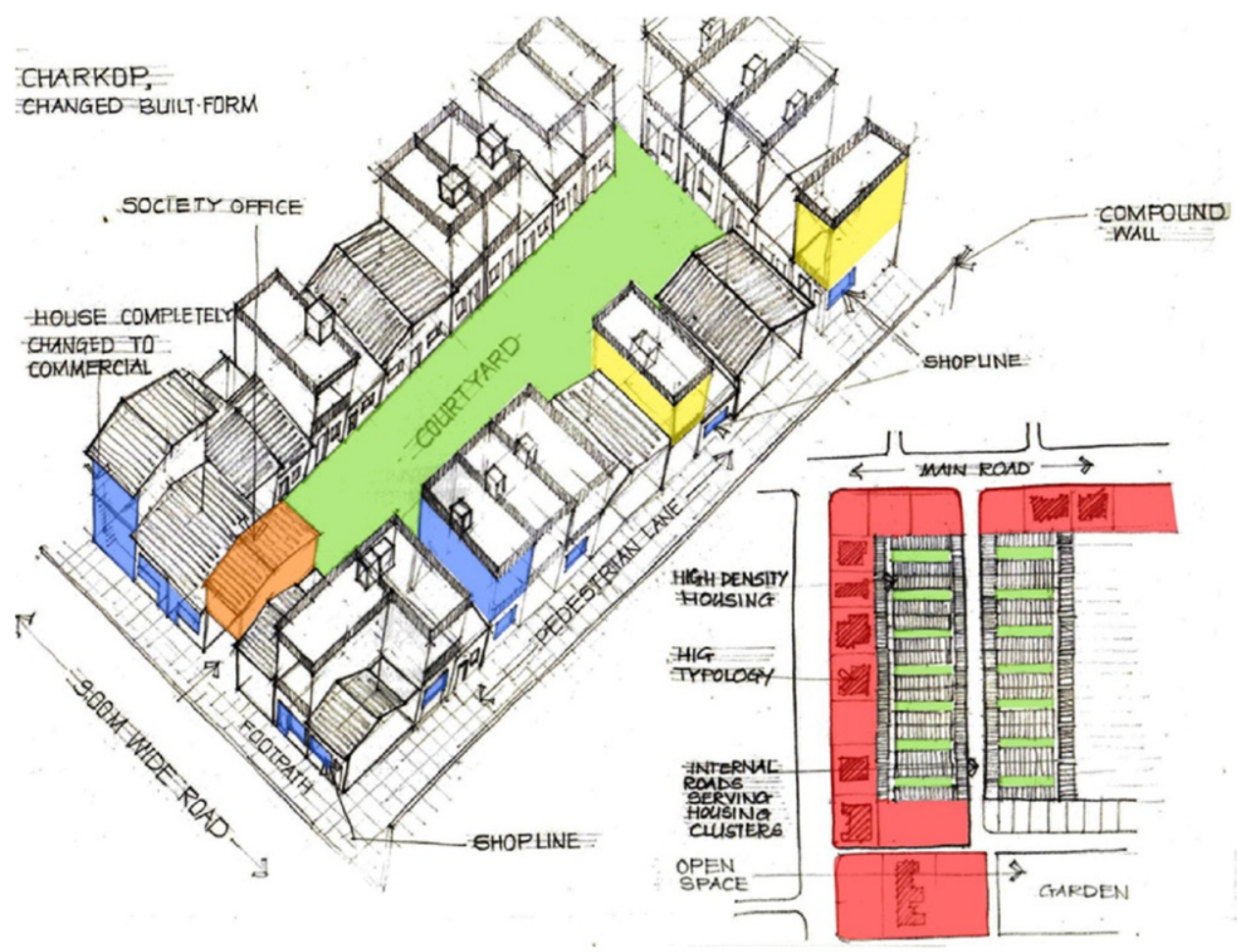

Figure 3. Part plan of sector and detail of L.I.G. cluster, Charkop (source: author) 


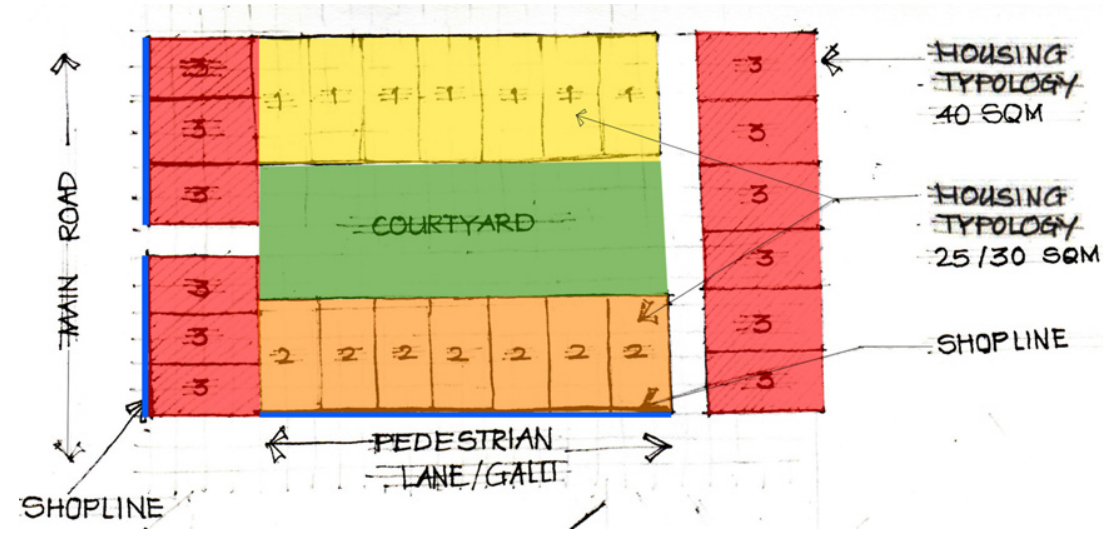

Figure 4. Plan of L.I.G. housing society cluster, Charkop (source: author)

The Charkop project is based on a cross-subsidy model. The site was divided into various sectors bounded by $12 \mathrm{~m}$ wide roads. Plots facing the $12 \mathrm{~m}$ wide roads were sold at market rates to commercial and higher income group residential occupants. Plots for the urban poor were then provided at subsidised rates. The beneficiaries were divided into housing societies, which would each occupy one plot. The plot consists of a central courtyard surrounded by smaller plots allotted to each family (Figure 3). The courtyard is accessed by $9 \mathrm{~m}$ wide roads, which then lead to the main roads. The plots were offered to the beneficiaries with $10 \%$ down payment and the rest of the amount paid in 240 equated monthly payments at an interest of $12 \%$ p.a. The sites were provided with basic services such as water supply, electricity and sewage facilities, the cost of which was recovered from the beneficiaries, in addition to Municipal taxes and other consumption charges. The monthly outgoings were designed so that they would not exceed $20 \%$ of the monthly income of the beneficiaries (MHADA, 1987). The plots were divided into 25, 30 and $40 \mathrm{~m}^{2}$ categories and provided with a core house (Figure 4). The beneficiaries were expected to expand the core house as per their need and ability. MHADA provided typical designs for the houses, which included stage-wise construction information while MHADA specialists were available to provide technical expertise. The typical plans featured a house with a living room and kitchen as well as front and/or back open spaces depending on the location and size of the plot. Housing and Urban Development Corporation (HUDCO), a public sector undertaking of the Government of India tasked with addressing housing finance and urban infrastructure development issues) was approached to provide loans.

Along 30 years, the original core houses have been modified by individual owners and now exhibit a variety of typologies based on the location, size and need of the owners. The front and back open spaces have mostly been incorporated into the house. In many cases, a loft has been added, taking advantage of the 14' internal height of the unit. Some houses have added floors for either self-use or to create space for renting out to commercial or residential users (Figure 5). Many of the plots which have frontage onto the street have converted the front open space into retail outlets (Figure 5). Some units have completely changed from residential to retail spaces.

\section{Case 3: Kamla Nehru Nagar community managed eviction and resettlement}

In 1999, there were reportedly over 20000 families living in slums built on railway lands abutting the local train tracks in Mumbai (Patel, D'Cruz and Burra, 2002). The World Bank funded Mumbai Urban Transport Project necessitated the eviction and resettlement of these families. The bank has clear guidelines involving civil society involvement in the rehabilitation of the people affected by the projects funded by it (Hingorani, 2011a).

For a decade prior to the resettlement, the National Slum Dwellers Federation (NSDF) had been carrying out data collection and mapping exercises in the settlement along with the NGO Society for Promotion of Area Resource Centres (SPARC). The surveyed families set-up their own collective, the Railway Slum Dwellers Federation (RSDF). About $80 \%$ of the families were part of this union (Patel et al., 2002).

SPARC and NSDF along with a women's group called Mahila Milan formed a collaboration known as the Alliance. Mahila Milan (women together) had been created in 1987 as a collective of women among pavement dweller families. Its main aim is to create a space for women's contributions in low-income communities, in providing housing for the family and in managing community services (Entzer et al., 2000). 

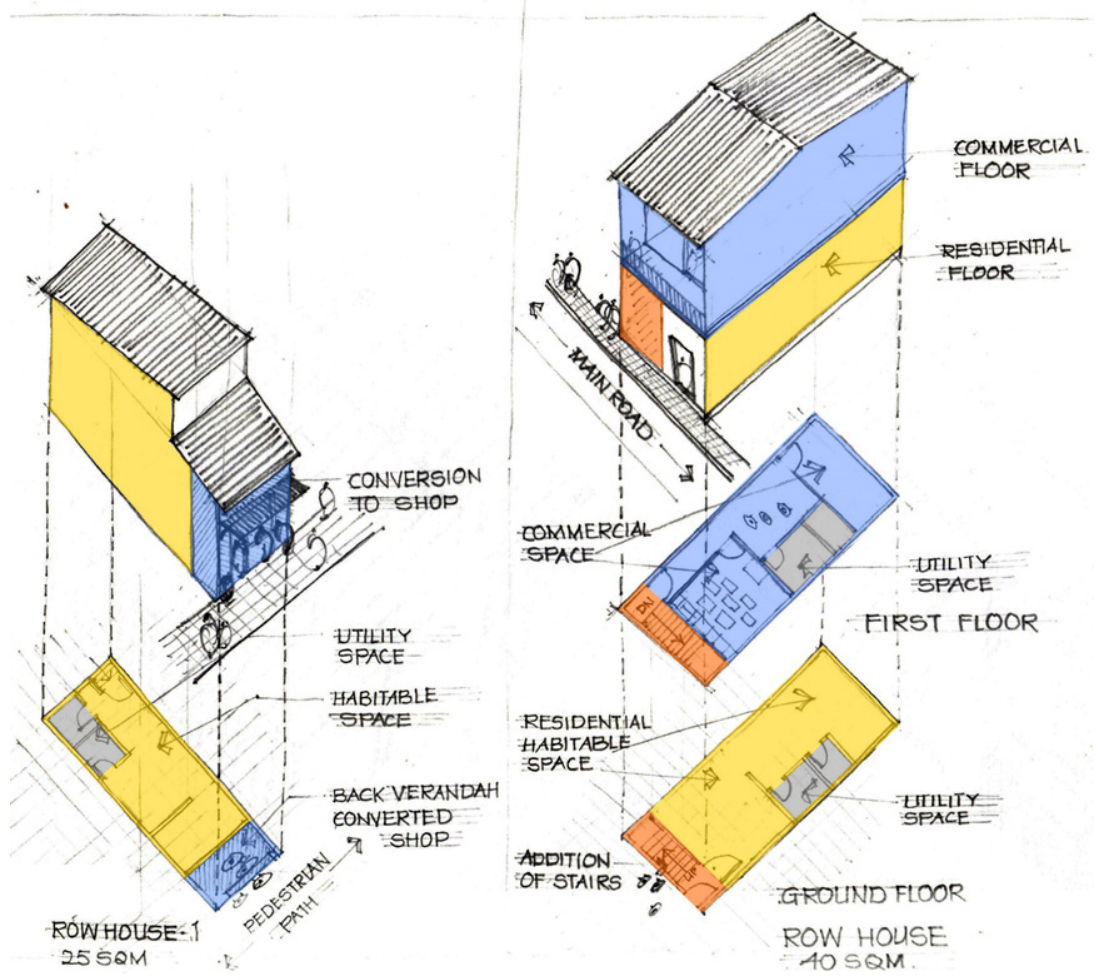

Figure 5. Built form studies of house typologies, Charkop (source: author)

The Alliance organised the slum dwellers into housing societies and encouraged them to think about the kind of housing they aspired to and what they could afford. They were asked to build life-sized models of these homes (Entzer et al., 2000). The RSDF showed their willingness to move in return for housing with secure tenure at appropriate location.

This eviction and resettlement approach was unique in that it caused little economic hardship to those resettled, it was voluntary without any external force and it involved the evicted households in the design, planning and implementation of the resettlement.

The process of rehabilitation as espoused by the World Bank consists of tendering and giving different contractors the responsibility for baseline socio-economic survey, drawing up the resettlement plan and implementation. However, in this case, both World Bank and MMRDA were willing to show some flexibility regarding the procedures in the interest of expediting the process of rehabilitation by giving the responsibilities solely to the Alliance (Hingorani, 2011a).

There were certain issues faced by the inhabitants after relocation. First, since the relocation site was four railway stations away from their original location, the people who were employed around their original location, especially the women who worked as maids in the houses of higher income groups found it difficult to travel to their old workplaces or to find employment in their new location. People who owned small shops found fewer customers in the new location. Second, the influx of population soon inundated social infrastructure facilities like schools in the new location, causing the need to start a bus service to ferry students to their old school.

The project is notable due to the involvement of Mahila Milan whose savings schemes helped the slum dwellers finance their future homes. The group also managed to provide a fund of INR 50 lakhs to deal with the problems faced by the residents after rehabilitation. The Mahila Milan savings and credit programme were aimed at creating capital for investments in shelter and to reduce vulnerability through providing an emergency fund. For this, two savings schemes were created - a 'daily savings scheme' for getting credit in case of crisis and a 'housing savings scheme'. In the daily savings scheme, women were encouraged to save money on a daily basis up to a limit that they could afford and deposit it with their respective Mahila Milan society. Each Mahila Milan society had a committee which was in charge of the cash, 
maintaining records and other administrative responsibilities. A loan committee decided on the loans which could be given. Each society was independent regarding the way they handled their savings. These small savings scheme created a fund through which immediate needs for money could be satisfied. They also empowered the women by imparting skill and confidence in handling monetary transactions.

The housing savings scheme involved collaborations with banks, where each member was supposed to open a bank account and save money for their future homes. Members could go to the bank themselves and deposit their savings in their account, or let the Mahila Milan leaders deposit the money on their behalf. Withdrawal of money had to be cleared by SPARC and Mahila Milan in order to make sure that it was only used for housing purposes. The existence of the crisis credit scheme ensured that even in case of emergencies, the housing savings were not depleted. The savings in the bank qualified the account holders for housing loans. Kamla Nehru Nagar residents, for example, had their accounts with Bank of Baroda. As per an agreement negotiated with the bank by the Alliance, a saved amount of INR 5000 (about US\$110) qualified the account holder for a loan of INR 20000 (about US $\$ 440$ ). In exceptional cases, the savings from the crisis credit schemes could be used to fulfill this amount, though this practice was not encouraged (Entzer et al., 2000).

\section{Case 4: Wasi Naka slum rehabilitation scheme}

For re-housing slum dwellers facing eviction due to large infrastructure projects, the Government of Maharashtra employed a public-private partnership model (CRIT \& JJ (JJCOA \& CRIT, 2010)). Private developers are called on to build tenements of $25 \mathrm{~m}^{2}$ each free of cost. In return, the developer gets incentives in the form of transferable development rights (TDR). This means that a developer can build these tenements where property prices are lower and use the TDR to build market rate housing where property prices are higher. Wasi Naka is one such resettlement colony.

The scheme consists of six to eight storey RCC-framed buildings built next to each other at a distance of $3 \mathrm{~m}$ (Figures 6 and 7). Each floor has 8-12 tenements of $25 \mathrm{~m}^{2}$ each. A tenement consists of a multi-purpose room, a kitchen and a toilet (Figure 6). Due to relaxation of norms, light, ventilation and fire safety regulations are overlooked, leading to unlivable conditions. Common facilities like lifts are often in a state of disrepair due to overuse and lack of maintenance.

Further, as the site is located on the outskirts of the city with few connections to the city, the residents find it extremely difficult to go to their places of work. Due to the isolated nature of the site, finding employment near the house also becomes difficult, leading to higher travelling costs and time (JJCOA \& CRIT, 2010).

\section{Part IV findings}

The case studies show three main ways in which the house is used as a source of income. In Kumbharwada, the house works as a space for production, storage as well as sale of a particular commodity. The built form of the house ensures that the users have access to a common shared space, which acts as additional space to accommodate shared resources such as kilns.

The second use to which the house is put is using part of the house as a retail space. In Kumbharwada and Charkop, it is

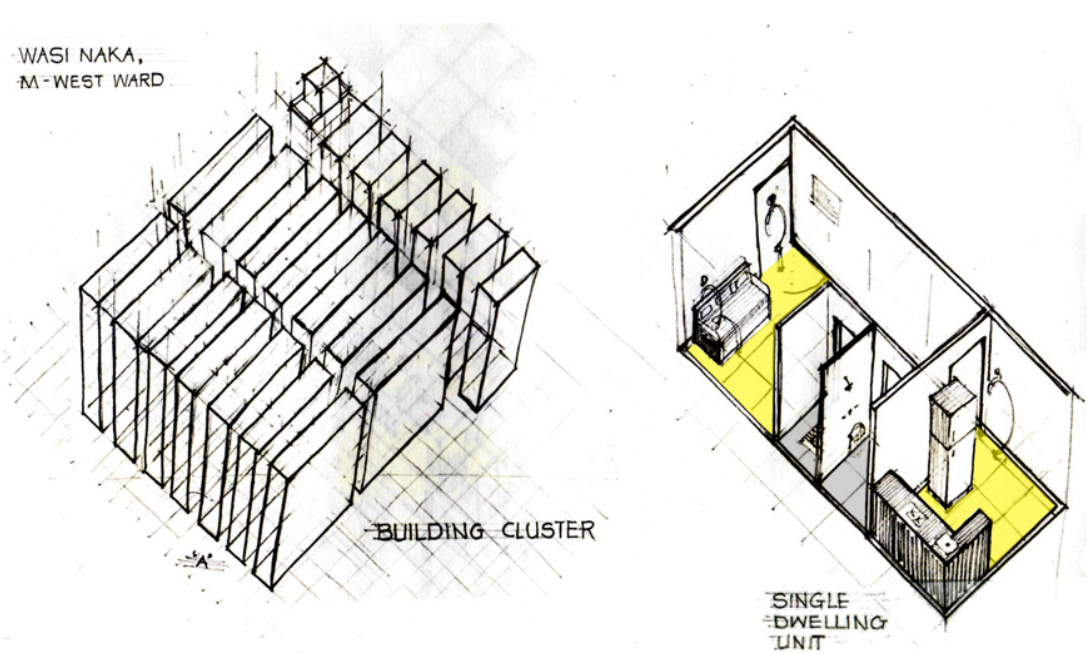

Figure 6. Building cluster and dwelling unit (source: author) 


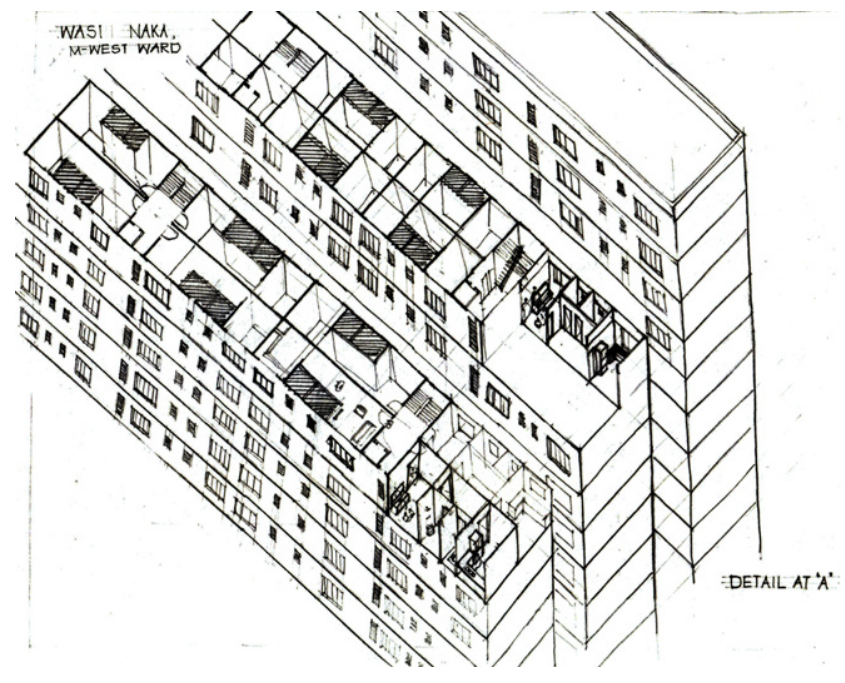

Figure 7. Built form studies of cluster, Wasi Naka rehabilitation scheme (source: author)

seen that retail spaces and businesses, which need visibility to attract clientele have come up where street frontage is available. This means that properties with such street frontage are at a premium. In Charkop, one finds that in houses facing public streets, the open spaces in the front have been converted into such retail spaces.

The third way in which the house generates income is by adding or converting part of existing space in the house for renting out to residential or commercial spaces. In Kumbharwada, one sees that many of the house owners have added floors to their existing houses and rented them out to people from outside the potter community. These tenants do not make use of the community facilities, which are for the use of the potters, but carry out other businesses such as tailoring or use the space for residence. In Charkop, houses with street frontage have added upper floors for either renting out as commercial spaces or to establish business offices or activities such as computer classes, tuitions and so on In the houses facing internal courtyards, the upper floors are mostly residential. In most cases, these upper floors are accessed separately from the front open space by means of ladder-like single-flight staircases.

Incrementality is a key factor in these cases. In both Kumbharwada and Charkop, the houses have evolved over time depending on the need and convenience of the owners. This incrementality is facilitated by the nature of the built form, which is of the row house type, where the width of the house is equal to the width of the plot. This does put restrictions on the length of the plot, as the houses can only get light and ventilation from the two narrow sides of the plot.
On the other hand, as seen in the case of Wasi Naka rehabilitation, the apartment typology gives no scope for incremental growth or flexible use of space, except perhaps on the ground floor. Also, it necessitates such facilities as lifts and common corridors, which increases the maintenance costs on the residents. The houses, far from being sources of income, are drains on the household's resources.

The residents of Charkop and Wasi Naka have security of tenure, which is absent in Kumbharwada. The Kamla Nehru Nagar residents also have secure tenure in the resettlement colonies. As the Vacant Land Tenancy has been cancelled, Kumbharwada residents face the threat of eviction by the authorities. This means that Kumbharwada residents have no incentive to invest in and improve their properties, which has led to slum-like conditions, with little access to basic infrastructure.

\section{Conclusion}

The ways in which urban poor households earn, save, spend and invest their income can be termed as the livelihood strategies. The poor tend to '... reduce risk, increase adaptability, and seek a degree of autonomy by developing and maintaining wider options, through the ability and willingness of different household members to do different things at different times' (Chambers, 1989: p. 3). The decentralisation of means of production has given rise to a city of entrepreneur agents, who operate out of workspaces distributed around the globe. Observations show that the urban house is used as a multifunctional space, which helps accommodate the entrepreneurial endeavours of these agents and also as a source of income generation through rents. The attributes of housing that allow this to happen and the ways in which they affect the value of the house as an entrepreneurial resource are discussed below.

While most housing schemes for the urban poor treat tenure as the primary focus, observations show that the importance of clear tenure for the poor lies in the security it provides. Provision of basic services to slums implicitly legitimises the efforts of the slum dwellers in providing housing for themselves. This security is essential to encourage the inhabitants to invest in the improvement of their houses. Improvements in the house increase its value.

These investments are done incrementally, depending on the priorities and the needs of the household and availability of finance. Thus, the ability to adapt to the changing needs of the household and grow over time is necessary. The apartment typology, which is generally adopted to fulfill the densities required in slum rehabilitation schemes, does not allow for this incrementality. On the other hand, informal housing and site 
and services schemes both thrive on the ability of the end user to invest incrementally.

Incremental growth in housing also means that housing finance needs to be made available incrementally as well. In order to modify or expand a house for income generation, the household needs to source its finance from loans, subsidies or own contributions. The housing finance market in India is underdeveloped at this point in time. Thus, the government relies on providing soft loans, which can be paid back over a long period of time. If the house is enabled to fulfill its income-generating capacity, the affordability of such loans increases. Self-help groups such as Mahila Milan help increase the access to housing finance.

In addition to the changes made internally, it is observed that the income generating capacity of the house is also helped by the access to shared spaces. This is especially true of communities that share a common economic activity. The shared spaces are used to accommodate commonly used facilities. Where retail spaces are concerned, road frontage is at a premium. Apartment typologies severely curtail the access of the houses to either facility.

Speaking of the location, one of the reasons for the dissatisfaction of the beneficiaries of slum rehabilitation programmes was the far-flung locations of the rehabilitation sites. This led to an increase in the travelling time and costs for getting to the place of work. Using the house as a workplace saves these costs. In addition, most rehabilitation sites do not feature a mix of income groups. Thus, the lower income groups find it difficult to find clientele near their new sites, leading to a loss of opportunities and income.

In a nutshell, in order to make housing truly affordable for the urban poor, it has to be taken into consideration that it is not only shelter that such housing is expected to provide. We have looked at what attributes allow a house to play this multi-functional role. However, another major aspect which emerges from the case studies is the level of community participation that was involved in the delivery of the housing. It can be said with some amount of confidence that there is a correlation between the satisfaction of the urban poor with the housing provided and the active role played by the beneficiaries in the process. Currently, the mechanisms for urban planning and housing provision in India cannot be said to be participatory in any true sense of the word. The argument can be made that this is one of the main reasons why affordable housing schemes in the country have struggled to find success.

Ultimately, the core question that is foregrounded is that of the right of the poor to the city. Housing that makes it feasible for the livelihood strategies of the urban poor to function is a key element in the creation of a truly inclusive entrepreneurial city.

\section{REFERENCES}

Chambers R (1989) Editorial introduction: vulnerability, coping and policy. IDS Bulletin 20(2): 1-7.

Entzer A, Lorenz H and Neudert E (2000) Slums in Transition: A Case Study of Resettlement of Railway Slums in Mumbai. KIT, Karlsruhe, Germany.

Gulyani S and Bassett EM (2010) The living conditions diamond: a theoretical and analytical framework for understanding slums. Environment and Planning A 42(9): 2201-2219.

Hingorani P (2011a) Housing solutions: a review of models. Proceedings of the India Urban Conference, Mysore, India. Indian Institute of Human Settlements, Bangalore, India.

Hingorani P (2011b) Revisiting low income housing: a review of policies and perspectives. Proceedings of the India Urban Conference, Mysore, India. Indian Institute of Human Settlements, Bangalore, India.

JJCOA \& CRIT (Sir J.J. College of Architecture \& Collective Research Initiatives Trust) (2010) Typologies and Beyond: Slum Settlement Studies in Mumbai. CRIT, Mumbai, India.

MHADA (Maharashtra Housing and Area Development Authority) (1987) Site and Services Scheme at Charkop-Kandivali Under Bombay Urban Development Project. Produced for the International Year of Shelter for the Homeless (IYSH), 1987. MHADA, Mumbai, India.

Patel S, D'Cruz C and Burra S (2002) Beyond evictions in a global city: people-managed resettlement in Mumbai. Environment and Urbanization 14(1): 159-172.

Shetty P (2005) Stories of Entrepreneurship. SARAI-CSDS, short term independent research fellowship programme. SARAI-CSDS, Mumbai, India.

Smets P (2004) Housing Finance and the Urban Poor. Rawat Publications, New Delhi, India.

SPARC \& KRVIA (Society for Promotion of Area Resource Centres \& Kamla Raheja Vidyanidhi Institute for Architecture) (2010) ReDharavi. KRVIA, Mumbai, India.

Wadhwa K (1988) Housing programmes for urban poor: shifting priorities. Economic and Political Weekly 23(34): 1762-1767.

Wadhwa K (2009) Affordable Housing for Urban Poor. National Resource Centre, New Delhi, India. See http://www.spa.ac. in/NRC/ThemePaperAffordableHousing.pdf (accessed 16/04/2017).

\section{How can you contribute?}

To discuss this paper, please email up to 500 words to the editor at journals@ice.org.uk. Your contribution will be forwarded to the author(s) for a reply and, if considered appropriate by the editorial board, it will be published as discussion in a future issue of the journal.

Proceedings journals rely entirely on contributions from the civil engineering profession (and allied disciplines). Information about how to submit your paper online is available at www.icevirtuallibrary.com/page/authors, where you will also find detailed author guidelines. 